\title{
Molecular typing of Legionella pneumophila serogroup 1 isolates from patients and the nosocomial environment by arbitrarily primed PCR and pulsed-field gel electrophoresis
}

\author{
CHRISTINE LAWRENCE, ESTHEL RONCO, SYLVIE DUBROU*, ROLAND LECLERCQ $\dagger$. \\ CHARLES NAUCIEL and PEGGY MATSIOTA-BERNARD
}

Laboratoire de Microbiologie, Hôpital Raymond Poincaré, 92380 Garches, * Laboratoire d'Hygiène de la Ville de Paris and †Laboratoire de Bactériologie-Virologie-Hygiène, Hôpital H. Mondor, Créteil, France

\begin{abstract}
The ubiquity of Legionella pneumophila in aquatic habitats means that epidemiological evaluation is important for the investigation and control of nosocomial outbreaks of legionellosis. Pulsed-field gel electrophoresis (PFGE) of chromosomal DNA following digestion with $S f I$ is considered to be one of the most discriminative methods for detecting DNA polymorphisms amongst $L$. pneumophila serogroup $1(L p 1)$ isolates. This paper describes an arbitrarily primed PCR (AP-PCR) method with three different primers (20-mers) for detecting DNA polymorphisms of $L p 1$ isolates. The AP-PCR assay was compared with PFGE analysis. Both experimental methods were found to have good discriminatory power (discrimination index of $98 \%$ and $94.3 \%$, respectively) with 27 unrelated isolates from different geographical areas collected between 1987 and 1997. Furthermore, when the AP-PCR was used in the epidemiological investigation of nosocomial cases of infection, convergent results with the three primers allowed an epidemiological link to be established between isolates from patients and their environment. The AP-PCR method, which is rapid and easy to perform, gave results at least as discriminatory as those obtained with the PFGE method and is proposed for use in the molecular typing of $L p 1$ outbreaks.
\end{abstract}

\section{Introduction}

Legionella pneumophila was first isolated following an outbreak of severe pneumonia in Philadelphia in 1976 [1]. Although many Legionella species are found in the natural environment, L. pneumophila is responsible for $>85 \%$ of cases of Legionnaires' disease [2]. Outbreaks of community-acquired and nosocomial L. pneumophila infection have been described [1,3]. During such outbreaks, epidemiological studies are required to identify the environmental source of the infection and a possible epidemiological link between the cases. Serotyping of L. pneumophila isolates with specific antibodies is used widely, but is of limited value as most L. pneumophila infections involve serogroup 1 [2]. Other epidemiological markers used in the investigation of legionellosis include monoclonal antibody subtyping of serogroup 1 [4], analysis of allo-enzymes [5] and

Received 23 April 1998; revised version received 15 June 1998; accepted 28 July 1998.

Corresponding author: Dr C. Lawrence. plasmids [6], and restriction endonuclease digestion of chromosomal DNA [3]. Restriction fragments of $L$. pneumophila DNA have been used as probes for molecular typing of nosocomial isolates belonging to the same serogroup (serogroup 3) [7]. Ribotyping has also been used to study the epidemiology of Legionnaires' disease $[7,8]$, but with conflicting results.

PCR fingerprinting with arbitrary primers can also be performed easily when epidemiological investigation is required [9]. A combination of ribotyping and arbitrary primed PCR (AP-PCR) with one arbitrary primer $[10,11]$ has been used previously for molecular typing of L. pneumophila epidemic isolates. In the present study, an attempt was made to improve the AP-PCR method by the use of three arbitrary primers. To validate this method, AP-PCR patterns of related and unrelated isolates were compared with those obtained after restriction endonuclease digestion of chromosomal DNA and analysis by pulsed-field gel electrophoresis (PFGE). PFGE is considered to be one of the most discriminative methods for detecting DNA 
polymorphisms among $L$. pneumophila serogroup 1 ( $L p 1)$ isolates $[8,12,13]$. The AP-PCR method was then used to study the epidemiological links and the environmental origin of $L$. pneumophila isolates involved in nosocomial cases of infection in two different hospitals.

\section{Materials and methods}

\section{Clinical isolates}

In total, $49 L p 1$ isolates were studied (Table 1). Five unrelated strains from different geographical areas and the reference strain Philadelphia 1 (ATCC strain 33152) were obtained from the French National Reference Center in Lyon. Twenty-one clinical isolates were obtained in this laboratory from bronchoalveolar lavage fluids or bronchial aspirates from patients hospitalised in the Paris area. These isolates, obtained in 1987-1997 from patients in 19 different hospitals, were considered to be unrelated. In addition, isolates from two nosocomial investigations were included. The clinical isolate of $L$. pneumophila from hospital A was compared with two environmental isolates by PFGE and AP-PCR. The investigation was then continued with the AP-PCR assay alone on 10 other $L p 1$

Table 1. Epidemiological data and molecular characterisation of the L. pneumophilia serogroup 1 isolates studied

\begin{tabular}{|c|c|c|c|c|c|c|c|c|}
\hline \multirow{2}{*}{$\begin{array}{l}\text { Isolate } \\
\text { designation }\end{array}$} & \multirow[b]{2}{*}{ Area* } & \multirow{2}{*}{$\begin{array}{c}\text { Hospital } \\
\text { designation }\end{array}$} & \multirow[b]{2}{*}{ Source } & \multirow{2}{*}{$\begin{array}{l}\text { Date of } \\
\text { isolation }\end{array}$} & \multicolumn{3}{|c|}{ AP-PCR type } & \multirow[b]{2}{*}{ Pulsotype } \\
\hline & & & & & IR6110 & LEG-2 & B1245 & \\
\hline \multicolumn{9}{|c|}{ Unrelated isolates } \\
\hline $\mathrm{Cl}$ & $\mathrm{P}$ & $\mathrm{C}$ & Patient & $06 / 1996$ & A & 1 & a & I \\
\hline D1 & $\mathrm{P}$ & $\mathrm{D}$ & Patient & $06 / 1991$ & A & 1 & a & I \\
\hline$E 1$ & $\mathbf{P}$ & $E$ & Patient & $06 / 1988$ & A & 1 & a & I \\
\hline$A 14$ & $\mathbf{P}$ & A & Patient & $04 / 1997$ & A & 1 & a & I \\
\hline$F I$ & $\mathrm{P}$ & $\mathrm{F}$ & Patient & $09 / 1995$ & B & 1 & a & I \\
\hline$G 1$ & $\mathrm{P}$ & G & Patient & $06 / 1996$ & $\mathrm{C}$ & 1 & a & I \\
\hline II & $\mathrm{P}$ & I & Patient & $07 / 1994$ & $\mathrm{E}$ & 2 & b & Ila \\
\hline$J 1$ & $\mathbf{P}$ & $\mathbf{J}$ & Patient & $06 / 1992$ & $\mathrm{E}$ & 2 & c & IIb \\
\hline$A 15$ & $\mathrm{P}$ & A & Patient & $09 / 1996$ & $\mathrm{E}$ & 11 & d & IIc \\
\hline A16 & $\mathbf{P}$ & A & Patient & $07 / 1994$ & $\mathrm{E}$ & 2 & $\mathrm{~d}$ & IIa \\
\hline$K 1$ & $\mathrm{P}$ & $\mathrm{K}$ & Patient & $10 / 1995$ & $\mathrm{E}$ & 2 & $\mathrm{e}$ & $\mathrm{IIb}$ \\
\hline$L 1$ & $\mathrm{P}$ & $\mathrm{L}$ & Patient & $04 / 1996$ & $\mathrm{E}$ & 2 & $\mathrm{f}$ & IIb \\
\hline$B 10$ & $\mathrm{P}$ & B & Patient & $07 / 1994$ & $\mathrm{~F}$ & 2 & d & Ile \\
\hline$M l$ & $\mathrm{P}$ & M & Patient & $10 / 1993$ & $\mathrm{~F}$ & 2 & $\mathrm{~d}$ & IIe \\
\hline$N I$ & $\mathrm{P}$ & $\mathrm{N}$ & Patient & $01 / 1997$ & $\mathrm{~F}$ & 2 & $\mathrm{~g}$ & IIf \\
\hline$O 1$ & $\mathrm{P}$ & $\mathrm{O}$ & Patient & $07 / 1987$ & G & 2 & $\mathrm{~h}$ & III \\
\hline$P I$ & $\mathrm{P}$ & $P$ & Patient & $10 / 1991$ & $\mathrm{E}$ & 3 & $\mathrm{i}$ & IV \\
\hline$Q I$ & $\mathrm{P}$ & $\mathrm{Q}$ & Patient & $12 / 1995$ & $\mathrm{H}$ & 4 & $\mathrm{j}$ & $\mathrm{V}$ \\
\hline$R I$ & $P$ & $\mathrm{R}$ & Patient & $03 / 1996$ & I & 5 & $\mathrm{k}$ & VI \\
\hline$S 1$ & $P$ & $\mathrm{~S}$ & Patient & $05 / 1996$ & $\mathbf{J}$ & 6 & 1 & VII \\
\hline$T I$ & $P$ & $\mathrm{~T}$ & Patient & $10 / 1987$ & $\mathrm{~K}$ & 7 & $\mathrm{~m}$ & VIII \\
\hline$U 1$ & $\mathrm{~T}$ & $\mathrm{U}$ & Patient & $05 / 1997$ & $\mathrm{O}$ & 8 & $q$ & $\mathrm{X}$ \\
\hline$V I$ & $\mathrm{O}$ & V & Patient & $05 / 1997$ & $\mathrm{P}$ & 9 & $\mathrm{r}$ & $\mathrm{XI}$ \\
\hline$W I$ & $\mathrm{O}$ & W & Patient & $03 / 1997$ & $\mathrm{Q}$ & 9 & $\mathrm{a}$ & XII \\
\hline$X I$ & $\mathrm{O}$ & $\mathrm{X}$ & Patient & $06 / 1997$ & $\mathrm{R}$ & 10 & $\mathbf{s}$ & XIII \\
\hline$Y 1$ & $\mathrm{O}$ & $\mathrm{Y}$ & Patient & $05 / 1997$ & $\mathrm{~S}$ & 9 & $\mathrm{t}$ & XIV \\
\hline ATCC 33152 & & & Ref. strain & & $\mathrm{E}$ & 2 & $\mathrm{u}$ & IId \\
\hline \multicolumn{9}{|c|}{ Nosocomial investigation A } \\
\hline Al & $\mathrm{P}$ & A & Patient & $10 / 1995$ & A & 1 & a & I \\
\hline$A 2$ & $\mathrm{P}$ & A & Environment & $11 / 1995$ & A & 1 & a & I \\
\hline$A 3$ & $\mathbf{P}$ & A & Environment & $11 / 1995$ & A & 1 & a & I \\
\hline$A 4$ & $\mathrm{P}$ & A & Environment & $11 / 1995$ & A & 1 & a & $\cdots$ \\
\hline$A 5$ & $\mathbf{P}$ & A & Environment & $11 / 1995$ & A & 1 & a & $\ldots$ \\
\hline$A 6$ & $\mathbf{P}$ & A & Environment & $05 / 1996$ & A & 1 & a & $\ldots$ \\
\hline$A 7$ & $\mathrm{P}$ & A & Environment & $05 / 1996$ & A & 1 & a & $\ldots$ \\
\hline$A 8$ & $P$ & A & Environment & $05 / 1996$ & A & 1 & a & $\ldots$ \\
\hline$A 9$ & $\mathrm{P}$ & A & Environment & $11 / 1995$ & $\mathrm{~L}$ & 1 & $\mathrm{n}$ & $\ldots$ \\
\hline$A 10$ & $\mathrm{P}$ & A & Environment & $05 / 1996$ & M & 1 & 0 & $\ldots$ \\
\hline$A I 1$ & $\mathrm{P}$ & A & Environment & $05 / 1996$ & M & 1 & 0 & $\ldots$ \\
\hline$A 12$ & $P$ & A & Environment & $05 / 1996$ & M & 1 & 0 & $\ldots$ \\
\hline$A 13$ & $\mathrm{P}$ & A & Environment & $05 / 1996$ & $\mathbf{M}$ & 1 & o & $\ldots$ \\
\hline \multicolumn{9}{|c|}{ Nosocomial investigation $\mathrm{B}$} \\
\hline$B 1$ & $\mathrm{P}$ & B & Patient & $12 / 1996$ & $\mathrm{E}$ & 2 & $\mathrm{~b}$ & IIa \\
\hline$B 2$ & $\mathrm{P}$ & B & Patient & $03 / 1996$ & $\mathrm{E}$ & 2 & $b$ & IIa \\
\hline$B 3$ & $\mathrm{P}$ & B & Patient & $03 / 1996$ & $\mathrm{E}$ & 2 & $\mathrm{~b}$ & IIa \\
\hline$B 4$ & $P$ & $\mathrm{~B}$ & Patient & $03 / 1996$ & $\mathrm{E}$ & 2 & $\mathrm{c}$ & IIb \\
\hline$B 5$ & $\mathrm{P}$ & B & Environment & $03 / 1996$ & $\mathrm{E}$ & 2 & b & Ila \\
\hline$B 6$ & $\mathbf{P}$ & B & Environment & $03 / 1996$ & $\mathrm{E}$ & 2 & $\mathrm{~b}$ & IIa \\
\hline$B 7$ & $\mathbf{P}$ & B & Environment & $03 / 1996$ & $\mathrm{E}$ & 2 & $b$ & $\ldots$ \\
\hline$B 8$ & $\mathbf{P}$ & B & Environment & $03 / 1996$ & D & 8 & $\mathrm{p}$ & $\ldots$ \\
\hline$B 9$ & $\mathbf{P}$ & B & Environment & $03 / 1996$ & D & 8 & $\mathrm{p}$ & $\ldots$ \\
\hline
\end{tabular}

${ }^{*} \mathrm{P}$, Paris area; $\mathrm{T}$, Tunisia; $\mathrm{O}$, other French areas. 
environmental isolates. Similarly, four clinical isolates and two environmental isolates obtained from hospital B over a 3-month period were compared by both methods. Three additional environmental isolates were studied by AP-PCR alone (Table 1).

All clinical specimens and the reference strain were cultured on buffered charcoal-yeast extract agar supplemented with $\alpha$-ketoglutaric acid (BCYE- $\alpha$ ) [14]. Environmental isolates were plated as recommended in the French standard AFNOR T90-431 for isolation of Legionella from potable water [15]. Serogrouping was based on reactivity with serogroup-specific fluorescent antisera (Centers for Disease Control, Atlanta, GA, USA).

\section{AP-PCR assay}

DNA was extracted from individual colonies with a DNA extraction reagent containing Chelex anionexchange resin (Perkin Elmer, Branchburg, NJ, USA) [16]. Bacteria were harvested from BCYE- $\alpha$ agar and suspended in $100 \mu 1$ of distilled water. The Chelex reagent $(200 \mu \mathrm{l})$ was added to the suspension and, after boiling for $25 \mathrm{~min}$ and centrifugation at $2000 \mathrm{~g}$ for 2 min, the supernates were used for AP-PCR analysis (see below).

Three primers were used for the AP-PCR method. Primer B1245 (5'-AGGTGGCGTCGAGGAAGAC-3') has been used previously for AP-PCR analysis of Mycobacterium avium [16]. Primer IR6110 (5'-CCCGGCATGTCCGGAGACTC-3') corresponds to the inverse repeat sequence of IS6110 found in the $M$. tuberculosis complex [17] and has already been used for AP-PCR analysis of $L$. pneumophila [11]. Primer LEG-2 (5'-CTGGCTTCTTCCAGCTTCA-3') has been used previously, combined with primer LEG-1, for the specific amplification of DNA from $L$. pneumophila strains [18].

PCR amplifications were performed in a total volume of $50 \mu \mathrm{l}$. Each PCR mixture consisted of $50 \mathrm{mM}$ Tris$\mathrm{HCl}(\mathrm{pH} 8.5), 17 \mathrm{mM} \quad\left(\mathrm{NH}_{4}\right)_{2} \mathrm{SO}_{4}, 2 \mathrm{mM} \mathrm{MgCl}_{2}$, $6.7 \mu \mathrm{M}$ EDTA, $10 \mathrm{mM} \quad \beta$-mercaptoethanol, bovine serum albumin (BSA) $0.1 \mathrm{mg} / \mathrm{ml}$, gelatin $0.1 \% \mathrm{w} / \mathrm{v}$, $200 \mu \mathrm{mol}$ of each deoxynucleoside triphosphate, $100 \mathrm{pmol}$ of arbitrary primers, and $0.5 \mathrm{U}$ of Taq DNA polymerase (Perkin Elmer). A $10-\mu 1$ portion of the DNA eluted from Chelex resin was added. Distilled water was used as a negative PCR control in place of Legionella DNA. The reaction mixtures were overlaid with $100 \mu \mathrm{l}$ of paraffin oil and incubated for $5 \mathrm{~min}$ at $94^{\circ} \mathrm{C}$, followed by 36 cycles of $92^{\circ} \mathrm{C}$ for $1 \mathrm{~min}, 35^{\circ} \mathrm{C}$ for $1 \mathrm{~min}$ and $72^{\circ} \mathrm{C}$ for $2 \mathrm{~min}$, with an additional final step at $72^{\circ} \mathrm{C}$ for $7 \mathrm{~min}$ (Hybaid Thermal Cycler; Hybaid Ltd, Teddington, Middlesex). DNA fragments were separated in agarose $2 \% \mathrm{w} / \mathrm{v}$ gels by electrophoresis and visualised by ethidium bromide staining. Gels were photographed and band patterns were compared visually. Very weak DNA bands were not taken into account. Two isolates were considered to have the same AP-PCR type when patterns with the three primers were identical. Some experiments were repeated after a new DNA extraction and the patterns were compared after co-migration on the same agarose gel to confirm the interpretation of the results.

\section{Chromosomal PFGE analysis}

Genomic DNA was prepared in agarose plugs [19]. Plugs were incubated in $3 \mathrm{ml}$ of lysis solution $(6 \mathrm{mM}$ Tris-HCl, $\mathrm{pH} 7.6,1 \mathrm{M} \mathrm{NaCl}, 100 \mathrm{mM}$ EDTA, $\mathrm{pH} 7.5$, Brij $580.5 \% \mathrm{w} / \mathrm{v}$, sodium deoxycholate $0.2 \% \mathrm{w} / \mathrm{v}$, sodium lauroyl sarcosine $0.5 \% \mathrm{w} / \mathrm{v}$, RNAase $20 \mu \mathrm{g} / \mathrm{ml}$, lysosyme $1 \mathrm{mg} / \mathrm{ml}$ ) for $24 \mathrm{~h}$ at $37^{\circ} \mathrm{C}$. This solution was replaced by $3 \mathrm{ml}$ of EPS solution ( $0.5 \mathrm{M}$ EDTA, $\mathrm{pH} 9$, proteinase $\mathrm{K} 50 \mu \mathrm{g} / \mathrm{ml}$, sodium lauroyl sarcosine $1 \% \mathrm{w} / \mathrm{v}$ ), incubated for $24 \mathrm{~h}$ at $50^{\circ} \mathrm{C}$, and then washed three times with $5 \mathrm{ml}$ of TE buffer $(10 \mathrm{mM}$ Tris- $\mathrm{HCl}$, pH 7.6, 1 mM EDTA). DNA was digested with $10 \mathrm{U}$ of Sf I (Pharmacia) by incubation overnight at $50^{\circ} \mathrm{C}$. DNA fragments were separated in agarose $1.2 \% \mathrm{w} / \mathrm{v}$ gels prepared and run in $0.5 \times$ Tris-borate-EDTA buffer in a contour-clamped homogeneous field apparatus (CHEFDR2; BioRad). Electrophoresis parameters were $200 \mathrm{~V}$ for $23 \mathrm{~h}$ at $4^{\circ} \mathrm{C}$ with pulse times ramped from 7 to $74 \mathrm{~s}$. Gels were then stained with ethidium bromide and photographed under UV illumination. Isolates with patterns that differed by three or fewer restriction fragments were classified as subtypes of the same pulsotype (Ia, Ib, Ic, etc.), while isolates differing by more than three restriction fragments were considered sufficiently divergent to warrant a separate pulsotype designation (I, II, III, etc.) [20, 21].

\section{Discrimination index}

The discriminatory power of each typing method was evaluated by calculating the index of discrimination (ID) proposed by Hunter and Gaston [22]. Subtypes of the same pulsotype were considered as different types when calculating this index for the PFGE method.

\section{Results and discussion}

Of the 10 primers tested with the reference strain in the AP-PCR assay, only three gave patterns with more than four bands (data not shown) and these were used subsequently in this study.

The performance and convenience of the AP-PCR method was evaluated by comparing it with the PFGE method for 27 unrelated isolates. The PFGE method yielded 13 pulsotypes, including one (pulsotype II) with six subtypes, resulting in an ID of $94.3 \%$ (Fig. 1 and Table 1). The AP-PCR assay yielded 15 patterns 


\section{$\begin{array}{lllllllllll}\text { F1 } & \text { K1 } & \text { Q1 } & \text { C1 } & \text { B4 } & \text { R1 } & \text { L1 } & \text { S1 } & \text { G1 } & \text { M }\end{array}$}

a

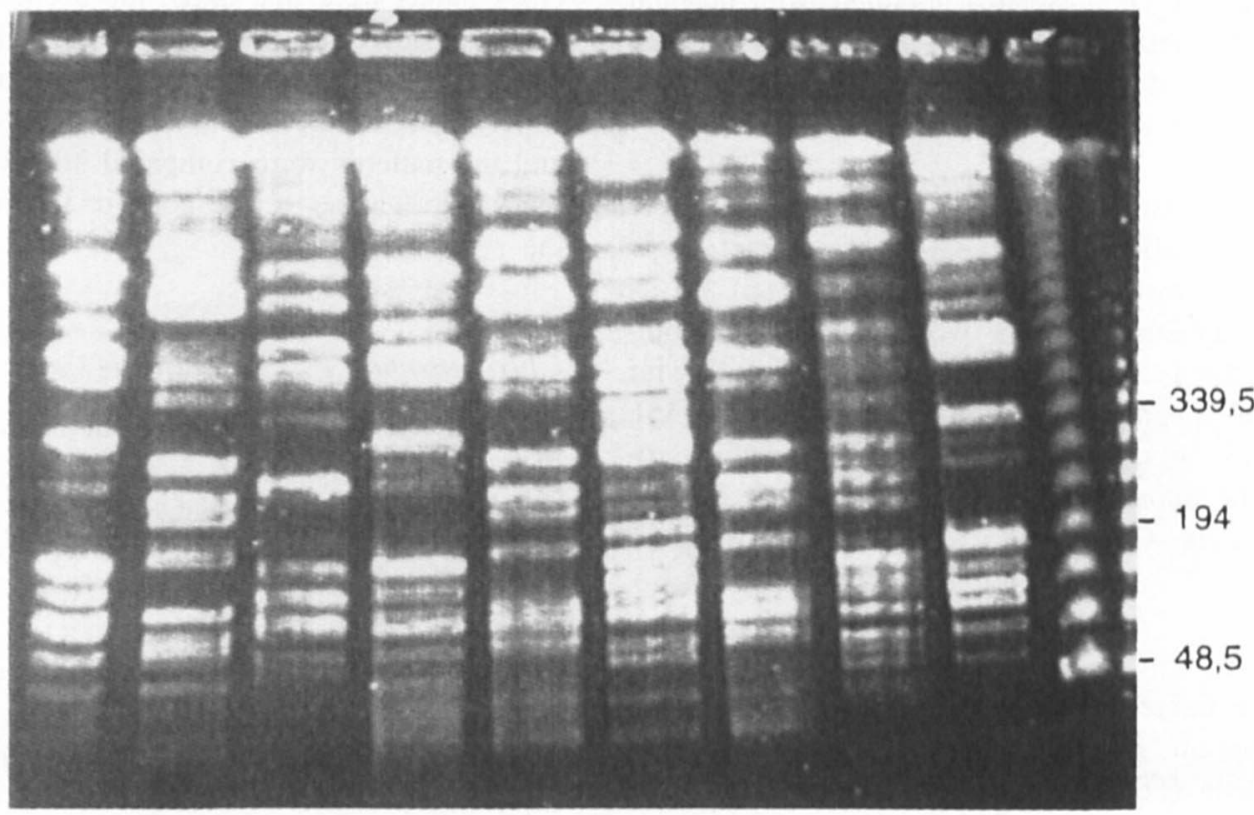

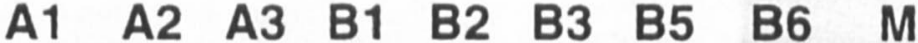

b

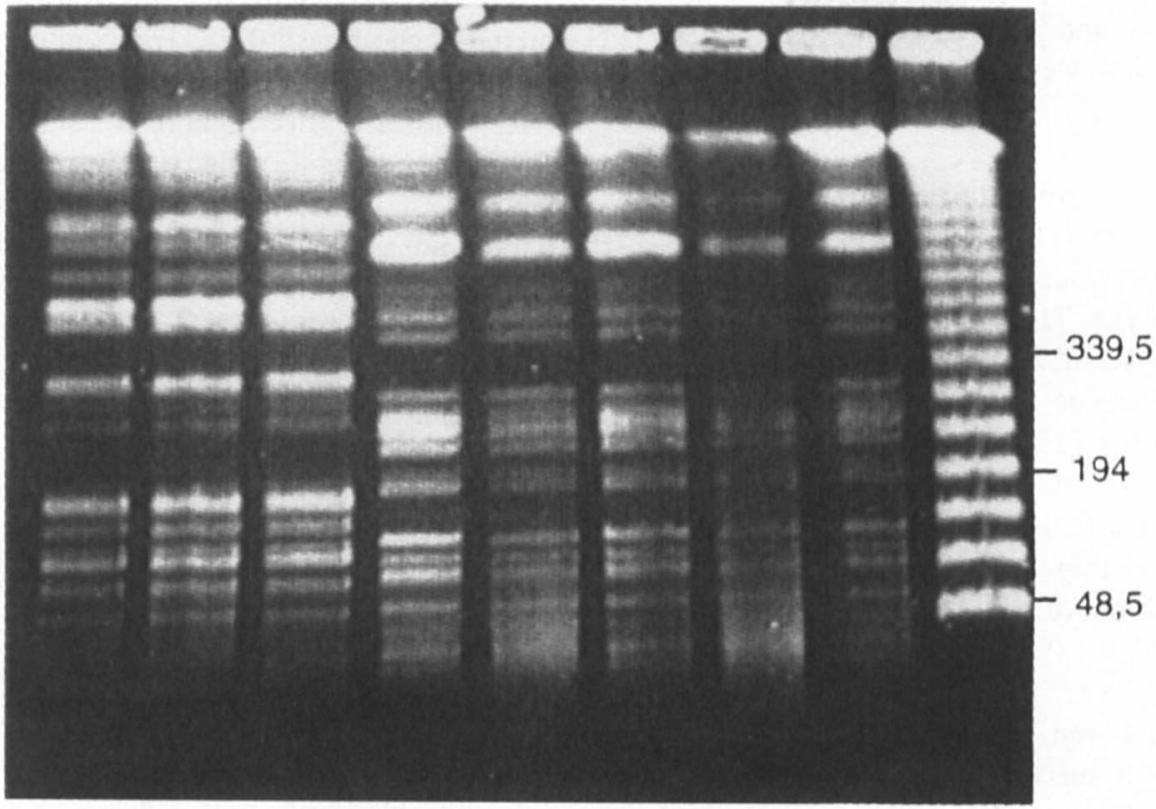

Fig. 1. Representative pulsotypes of (a) unrelated and (b) related L. pneumophila isolates after digestion by SfII. Letters refer to strains described in Table 1. Lane $\mathbf{M}$, size markers $(\mathrm{kb})$.

with primer IR6110, 11 patterns with primer LEG-2 and 18 patterns with primer B1245. The combination of the AP-PCR patterns with the three primers resulted in 23 AP-PCR types (Fig. 2 and Table 1), resulting in an ID of $98 \%$. In total, 21 patterns obtained with the AP-PCR method corresponded to single isolates; the two remaining patterns were obtained from two clusters of four and two isolates, respectively (Table 1). Cluster A1a included four clinical isolates obtained in different hospitals in 1988-1997 in the Paris area and corresponded to a single pulsotype (pulsotype I). The second cluster included two isolates from two different hospitals from the Paris area with the same AP-PCR type F2d and the same pulsotype IIe. Although the isolates in these clusters were distant in time and were not isolated from the same hospital, an epidemiological link could not be excluded.

PFGE is time-consuming and requires expensive equipment that is not available in all microbiology laboratories. The AP-PCR method, which was easy to 
M F1 K1 Q1 C1 B4 R1 L1 S1 G1 M

a

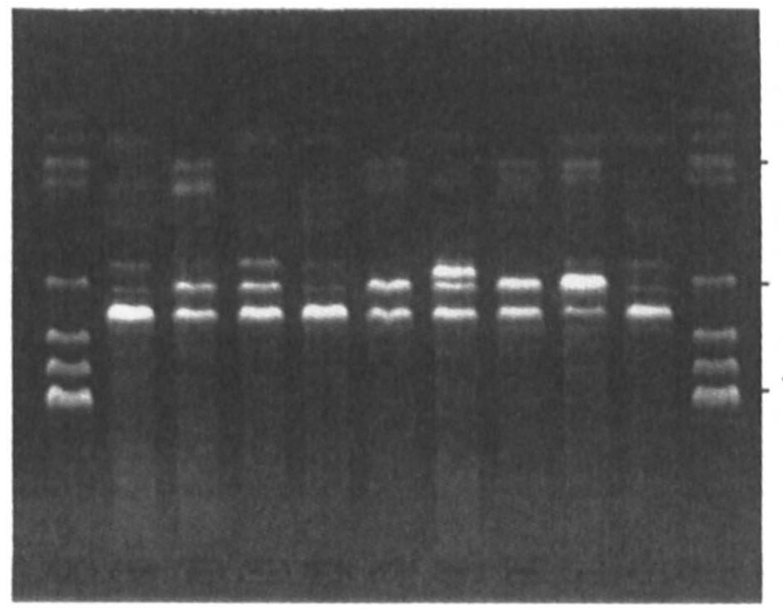

M F1 K1 Q1 C1 B4 R1 L1 S1 G1 M

b

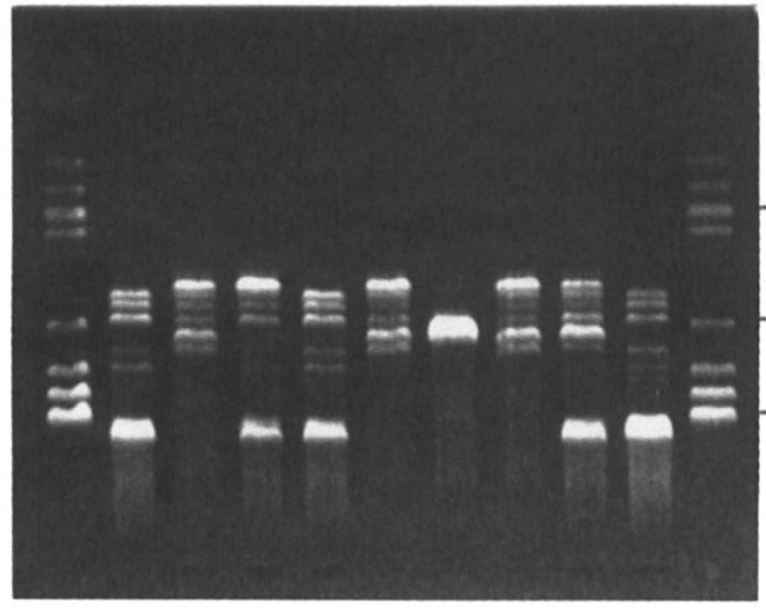

M F1 K1 Q1 C1 B4 R1 L1 S1 G1 M

C

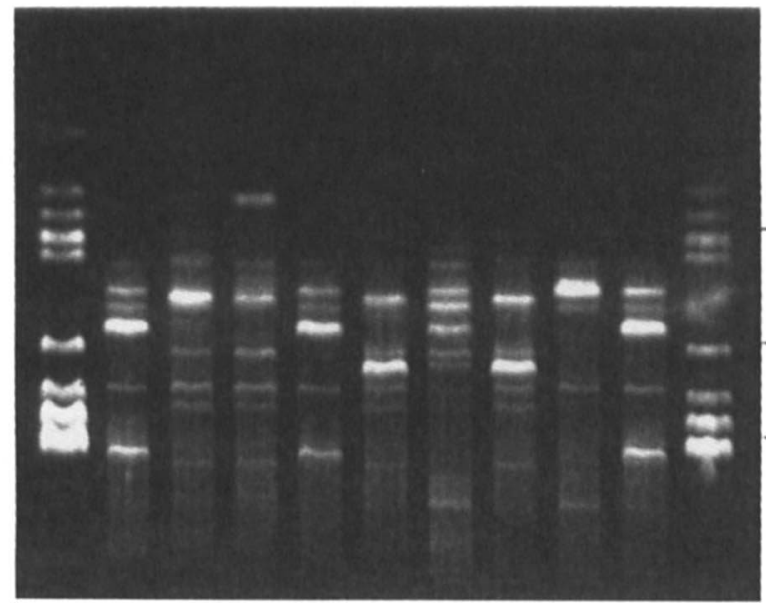

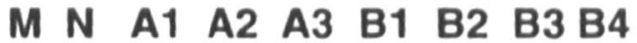

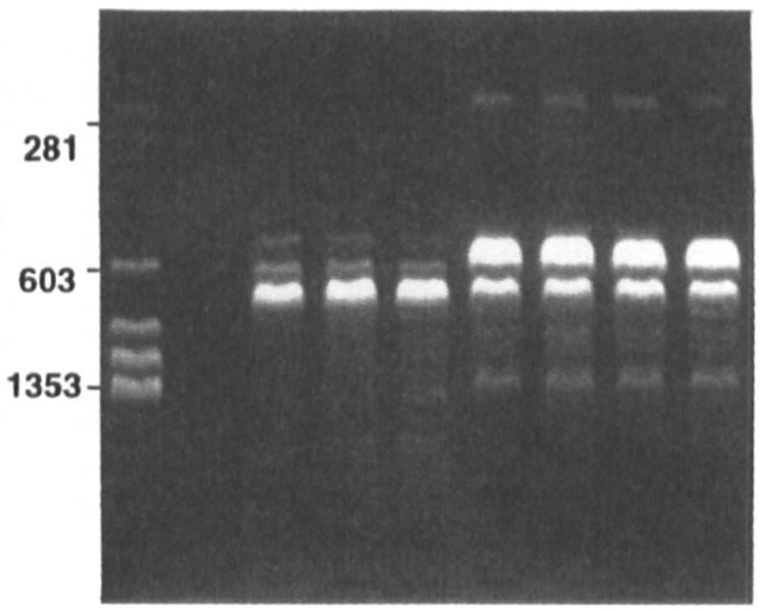

M N A1 A2 A3 B1 B2 B3 B4

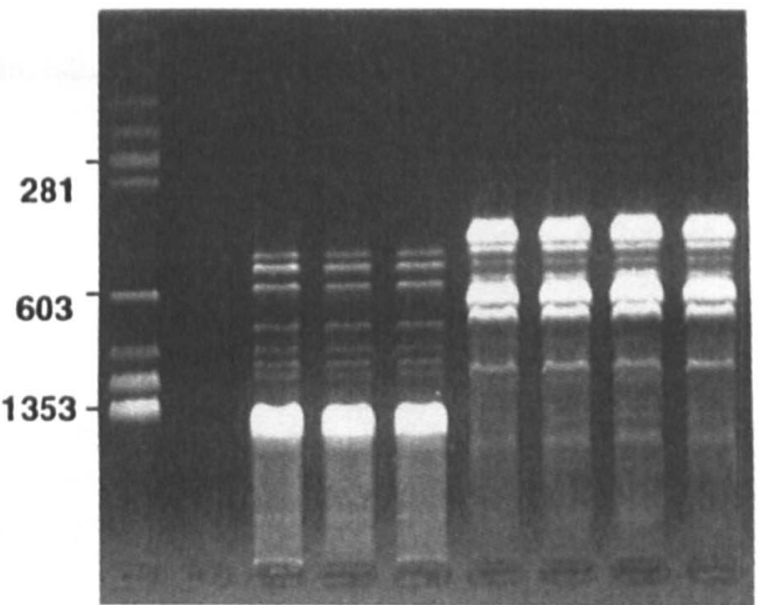

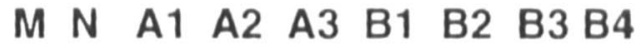

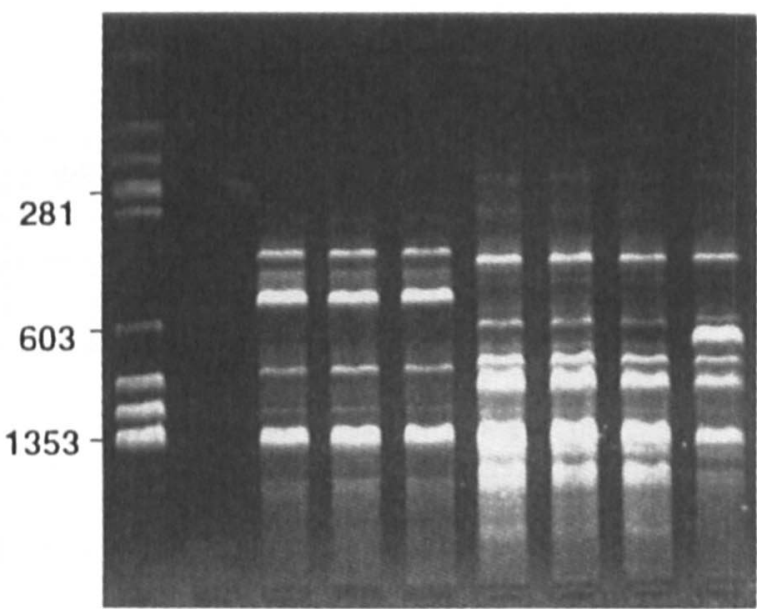

Fig. 2. Representative AP-PCR types of L. pneumophila unrelated (left) and related (right) strains with (a) primer IR6110, (b) primer LEG-2, (c) primer B1245. Letters refer to strains described in Table 1. Lane M, size markers (kb). $\mathbf{N}$, negative controls.

perform and gave fast results, appeared to be more convenient for descriptive epidemiological studies. Therefore, this method was chosen to identify the environmental origin of isolates associated with nosocomially acquired Legionnaires' disease. The PFGE method was then used to confirm the results of the AP-PCR method on chosen isolates (mentioned when used). 
The first case studied occurred in hospital A, where a $L p 1$ isolate was obtained from bronchoalveolar lavage fluid. The patient concerned was hospitalised for several weeks in the rehabilitation department. The AP-PCR patterns of the clinical isolate were compared to the patterns obtained with 12 environmental isolates obtained from the water supply in the same and different buildings of the hospital, before and after thermal shock. The same AP-PCR profile, Ala, was obtained for the clinical isolate $(A I)$ and for isolates from the patient's close environment, i.e., from his bedroom shower and sink hot water taps (isolates $A 2$ and $A 3$ ). These three isolates were also identical by PFGE. However, while some $L p 1$ isolates from the hospital environment had different patterns (isolates $A 9-A 13$ ), environmental isolates from other buildings before and after the thermal shock were also found to have the A1a AP-PCR profile (isolates $A 3-A 8$ ) (Table 1). Three L. pneumophila serogroup 2 isolates and seven L. pneumophila serogroup 3 isolates obtained from the hospital environment showed different patterns to the clinical isolate and the $L p 1$ environmental isolates (data not shown).

The second study was performed in hospital B, where three cases of Legionnaires' disease occurred in the haematology department in 3 months. These three patients were transferred to an intensive care unit, where a fourth case occurred. Five strains were isolated later from the environment. The AP-PCR patterns of the three clinical isolates $(B 1, B 2, B 3)$ and the isolate (B5) obtained from the hot water supply of the patients' bedroom in the haematology department were identical with the three primers used for AP-PCR (AP-PCR type E2b) and with the PFGE method (pulsotype IIa). Identical patterns were also obtained by AP-PCR and PFGE for an isolate $(B O)$ from the fibroscopy room water supply. The isolate from the fourth patient differed in its AP-PCR pattern with primer B1245 (one strong extra band; AP-PCR type E2c) and by PFGE subtype (IIb) (Fig. 2 and Table 1). This case is difficult to interpret as only minor differences were observed compared to the outbreak strain. However, differences were observed by both molecular typing methods. Furthermore, it is noteworthy that this fourth patient had never been hospitalised in the haematology department. In contrast, the other three patients developed Legionnaires' disease in the haematology department, and the environmental origin of the infection was localised to this department.

Van Belkum and Pruckler have shown that PFGE is more discriminative than AP-PCR, but only one or two arbitrary primers were used $[9,11]$. In the present study, the AP-PCR method was found to have a higher ID than the PFGE method (98\% and 94.3\%, respectively), even when subtypes were considered as different. Although AP-PCR with primer B1245 was more discriminatory than AP-PCR with the two other primers, convergent results with the three primers confirmed the results and some isolates could be discriminated only by the use of primer IR6110 (APPCR types Bla and C1a or types E2d and F2d) or primer LEG-2 (AP-PCR types E11d and E2d). When unrelated clinical isolates were studied by both molecular typing methods, some were found to form clusters. Whether this resulted from the fact that the number of virulent $L p 1$ strains isolated from patients was smaller than the number of environmental strains remains to be determined. Another possibility is the existence of common unknown environmental origins of legionellosis in the Paris area.

In conclusion, the major advantages of the AP-PCR method include technical simplicity, wide availability of equipment and reagents, and speed. This study assessed the method in comparison with PFGE and demonstrated that AP-PCR could be used with efficacy to demonstrate an epidemiological link between clinical isolates during an outbreak and to identify the environmental origin. These molecular typing methods should help to elucidate how Legionnaire's disease occurs and why these organisms are the cause of many community and nosocomial outbreaks of infection.

\section{References}

1. Fraser DW, Tsai TR, Orenstein W et al. Legionnaires' disease: description of an epidemic of pneumonia. N Engl J Med 1977; 297: $1189-1203$.

2. Marston BJ, Lipman HB, Breiman RF. Surveillance of Legionnaires' disease. Risk factors for morbidility and mortality. Arch Intern Med 1994; 154: 2417-2422.

3. Struelens MJ, Maes N, Rost F et al. Genotypic and phenotypic methods for the investigation of nosocomial Legionella pneumophila outbreak and efficacy of control measures. $J$ Infect Dis 1992; 166: 22-30.

4. Para MF, Plouffe JF. Production of monoclonal antibodies to Legionella pneumophila serogroups 1 and 6. J Clin Microbiol 1983; 18: 895-900.

5. Selander RK, McKinney RM, Whittam TS et al. Genetic structure of populations of Legionella pneumophila. $J$ Bacteriol 1985; 163: $1021-1037$.

6. Nolte FS, Conlin CA, Roisin AJM, Redmond SR. Plasmids as epidemiological markers in nosocomial Legionnaires' disease. $J$ Infect Dis 1984; 149: 251-256.

7. Tram G, Simonet M, Nicolas M-H et al. Molecular typing of nosocomial isolates of Legionella pneumophila serogroup 3. $J$ Clin Microbiol 1990; 28: 242-245.

8. Schoonmaker D, Heimberger T, Birkhead G. Comparison of ribotyping and restriction enzyme analysis using pulsed-field gel electrophoresis for distinguishing Legionella pneumophila isolates obtained during a nosocomial outbreak. $J$ Clin Microbiol 1992; 30: 1491-1498.

9. van Belkum A, Struelens M, Quint W. Typing of Legionella pneumophila strains by polymerase chain reaction-mediated DNA fingerprinting. $J$ Clin Microbiol 1993; 31: 2198-2200.

10. Grattard F, Berthelot P, Reyrolle M, Ros A, Etienne J, Pozzetto B. Molecular typing of nosocomial strains of Legionella pneumophila by arbitrarily primed PCR. J Clin Microbiol 1996; 34: 1595-1598.

11. Matsiota-Bernard P, Thierry D, Guesdon J-L, Nauciel C. Molecular epidemiology of Legionella pneumophila serogroup 1 by ribotyping with a non-radioactive probe and PCR fingerprinting. FEMS Immunol Med Microbiol 1994; 9: 23-28.

12. Pruckler JM, Mermel LA, Benson RF et al. Comparison of Legionella pneumophila isolates by arbitrarily primed PCR and 
pulsed-field gel electrophoresis: analysis from seven epidemic investigations. J Clin Microbiol 1995; 33: 2872-2875.

13. van Belkum A. DNA fingerprinting of medically important microorganisms by use of PCR. Clin Microbiol Rev 1994; 7 174-184.

14. Dournon E. Isolation of Legionellae from clinical specimens In: Harrison TG, Taylor AG (eds) A laboratory manual for Legionella. Chichester, John Wiley and sons. 1988: 13-30.

15. Association Française de Normalisation. Norme AFNOR T90 431. Essais des eaux. Recherche et dénombement des Legionella et L. pneumophila. Methodes générales par ensemensement direct et filtration sur membrane. 1993.

16. Matsiota-Bernard P, Waser S, Tassios PT, Kyriakopoulos A, Legakis NJ. Rapid discrimination of Mycobacterium avium strains from AIDS patients by randomly amplified polymorphic DNA analysis. $J$ Clin Microbiol 1997; 35: 1585-1588.

17. Thierry D, Brisson-Noël A, Vincent-Lévy-Frébault V, Nguyen S, Guesdon J-L, Gicquel B. Characterization of a Mycobacterium tuberculosis insertion sequence, IS6110, and its application in diagnosis. J Clin Microbiol 1990; 28: 2668-2673.

18. Stranbach MN, Falkow S, Tompkins LS. Species-specific detection of Legionella pneumophila in water by DNA amplification and hybridization. J Clin Microbiol 1989; 27: 1257-1261.

19. Murray BE, Singh KV, Don Heath J, Shama BR, Weinstock GM. Comparison of genomic DNAs of different enterococcal isolates using restriction endonucleases with unfrequent recognition sites. J Clin Microbiol 1990; 28: 2059-2063.

20. Goering RV. Molecular epidemiology of nosocomial infection: analysis of chromosomal restriction fragment patterns by pulsed-field gel electrophoresis. Infect Control Hosp Epidemiol 1993; 14: 595-600.

21. Tenover FC, Arbeit $\mathrm{RD}$, Goering $\mathrm{RV}$ et al. Interpreting chromosomal DNA restriction patterns produced by pulsedfield gel electrophoresis: criteria for bacterial strain typing. $J$ Clin Microbiol 1995; 33: 2233-2239.

22. Hunter PR, Gaston MA. Numerical index of the discriminatory ability of typing systems: an application of Simpson's index of diversity. $J$ Clin Microbiol 1988; 26: 2465-2466. 